\title{
Imports, Pass-Through, and the Structure of Retail Markets
}

\author{
Horst Raff \\ Nicolas Schmitt
}

\author{
CESIFO WORKING PAPER NO. 2817 \\ CATEGORY 8: TRAdE POLICY \\ OCTOBER 2009
}
An electronic version of the paper may be downloaded
- from the SSRN website:
- from the RePEc website:
- from the CESifo website:
www.SSRN.com
Www.RePEc.org
www.CESifo-group.org/wp




\title{
Imports, Pass-Through, and the Structure of Retail Markets
}

\begin{abstract}
We construct a model of trade with heterogeneous retailers to examine the effects of trade liberalization on retail market structure, imports and social welfare. We are especially interested in studying the degree of pass-through of import into retail prices and the effects of retail market regulation. The paper shows that the degree of pass-through may be large when market structure effects are taken into account, and that restrictions on retailing may have significant effects on imports and the degree of pass-through. The paper helps explain the apparent discrepancy between the low observed degree of pass-through and the large benefit that consumers seem to derive from trade liberalization.
\end{abstract}

JEL Code: F12, L11.

Keywords: international trade, retailing, pass-through, firm heterogeneity.

\author{
Horst Raff \\ Department of Economics \\ and Kiel Institute for the World Economy \\ Christian-Albrechts-University \\ 24098 Kiel \\ Germany \\ raff@econ-theory.uni-kiel.de
}

\author{
Nicolas Schmitt \\ Department of Economics \\ 8888 University Drive \\ Simon Fraser University \\ Burnaby BC, V5A 1 S6 \\ Canada \\ schmitt@sfu.ca
}

September 2009

The authors acknowledge financial support from the Social Sciences and Humanities Research Council of Canada. We thank Rolf Langhammer and Agnès Benassy-Quéré for information about German and French retailing. Thanks are also due to Martin Richardson and participants at the CESifo Area Conference on the Global Economy as well as various other conferences and workshops. 


\section{Introduction}

The purpose of this paper is to examine how the retailing sector responds to globalization and, in particular, to the increased scope to import consumer products. We are particularly interested in (i) the effects of trade liberalization on the structure and performance of the domestic retailing sector; (ii) how the structure of retail markets affects the transmission of external shocks, such as changes in import prices, into domestic retail prices; and (iii) how retail market regulation affects market structure, imports and retail prices. To study these issues we build a simple model of international trade with heterogeneous retailers and endogenous markups. The model helps reconcile the discrepancy between the low observed pass-through from import into consumer prices and the seemingly large benefit that consumers derive from increasing import penetration.

The structure of retail markets has changed dramatically in recent decades. Market concentration has increased markedly, driven by the emergence of large national chains operating large establishments. ${ }^{1}$ This concentration process has had a significant effect on international trade, as large retailers increasingly import consumer goods from low-wage countries like China. Basker and Van (2008b) for instance find that over the period 1997 to 2002 U.S. imports from China and other less-developed countries rose especially quickly in retail sectors with the largest consolidation into chains. Wal-Mart alone accounts for $15 \%$ of total US imports from China (Basker and Van, 2008a). ${ }^{2}$ This phenomenon is not limited to the United States and is taking place in many retail segments, including electronics, computers, cameras, housewares, toys, games, clothing, and footwear. ${ }^{3}$

\footnotetext{
${ }^{1}$ Whereas large retail firms (with at least 100 establishments) represented $18.6 \%$ of US retail sales in 1967, their share has increased to $36.9 \%$ in 1997, and the average size of these establishments is twice as large as it was 40 years ago. Overall, the retail and manufacturing sectors have similar ratios of single to multi-unit firms but, not surprisingly, multi-unit retailers operate more establishments on average than multi-unit manufacturers. More significantly, the number of establishments operated by multi-unit retailers has increased dramatically between 1977 and 1997 whereas it has decreased in manufacturing during the same period (Jarmin et al., 2005).

${ }^{2}$ Basker and Van (2008b) find that between 1997 and 2002 the biggest US retailers had a more than three times higher marginal propensity to import from China than smaller retailers. They argue that the expansion of big retailers accounts for $19 \%$ of the growth in US imports of consumer goods from China. On Wal Mart, see also Fishman (2006).

${ }^{3}$ For instance, in 2003, the share of imports in Canada was $55 \%$ for clothing, $82 \%$ for
} 
The paper is built on the idea that these changes in retail market structure have in part been brought about by two ingredients: the increased scope to import consumer goods from low-wage countries and economies of scale in importing. In such an environment, reductions in import prices, whether due to reductions in trade barriers or declining transportation and communication costs, benefit large retailers disproportionately, and by making large retailers more competitive, lower import prices tend to squeeze out smaller retailers.

What makes this simple mechanism appealing is that, when imbedded in a structural model of heterogenous retailers, it allows us to address several important policy issues. First, the benefits consumers may reap from trade liberalization depend crucially on how changes in import prices are passed through into consumer prices. Empirical evidence suggests that consumer prices tend to react very little to movements in import prices; this constitutes a major puzzle in international macroeconomics (Bacchetta and van Wincoop, 2003). Recent research on this issue (Campa and Goldberg, 2006a, 2006b; Hellerstein, 2008) suggests that the retail sector plays a central role in explaining pass-through, since distribution margins (i.e., retail costs and retailer mark-ups) typically account for 30 to 50 percent of the retail prices of consumer goods (Campa and Goldberg, 2006a). Any change in the cost structure and competition of the retail sector thus has a large impact on retail prices. By linking the pass-through of import prices into consumer prices to a structural model of retail markets, we are able to shed new light on this issue. Specifically, we decompose the degree of pass-through of import prices into the average domestic retail price into several distinct effects including changes in distribution margins and in the import share. We show that the degree of pass through into the average consumer price may be even larger than the pass-through into the average retail price of imports.

Second, many countries, including France, Belgium, Italy, Japan and the United Kingdom, are regulating retail markets, and in particular are limiting the size of new retail establishments. Our model allows us to examine how such regulations affect retail market structure, imports, retail prices and

clothing accessories, $86 \%$ for footwear, $100 \%$ for audio, video, small electrical appliances, as well as for toys and games (Jacobson, 2006, Table 33). It is precisely in these segments that the market share of large Canadian retailers is the highest: the market shares of the 80 largest retailers in 2004 represented $61 \%$ for clothing and accessories, $68 \%$ for home electronics, computers and cameras, $57 \%$ for housewares, $55 \%$ for toys and games and $49 \%$ for food. On average, this share was $27 \%$ for all the products sold by Canadian retailers (Jacobson, 2006, Table 6). 
ultimately welfare. This is especially interesting as there is evidence that, in the United States, it is the relatively poor consumers who benefit from the existence of large retailers such as Wal-Mart and from the high volume of non-durable products that these retailers import from China (Broda and Romalis, 2008). In France, however, there is evidence that lower import prices are not passed on to consumers, and consumers bitterly complain about the lack of price competition at the retail level (Economist, 2008). We show that retail regulations may indeed have strong negative effects on pass-through and welfare.

We investigate these issues in a model based on Melitz and Ottaviano (2008) who consider the selection of heterogeneous firms into export markets in a model with endogenous markups. By contrast, in our model it is retailers and thus importers that are heterogeneous. This modeling approach seems especially relevant, since the entry and exit of firms have been an important driving force behind the changes in retail market structure; in fact, both rates have been much higher in retailing than in manufacturing (see Jarmin et al., 2004). ${ }^{4}$

The basic mechanism at play in our model depends on large retailers choosing to source a share of their goods directly from abroad and not through domestic sourcing (either by buying domestically produced goods or products imported through independent intermediaries such as wholesalers or domestic subsidiaries of foreign exporters). A recent survey of Austrian, German and Swiss retailers (Zentes, Hilt and Domma, 2007) indicates that direct importing is indeed mostly done by large retailers, the largest of which operate their own overseas buying offices. ${ }^{5}$ It also argues that direct importing is associated with significantly lower variable costs, as it allows retailers to bypass additional layers of intermediaries through buying offices that can directly identify the lowest-cost supplier for specific items. The reason why only big retailers choose the direct import channel is, of course, that it is associated with large fixed costs. These include costs of operating buying offices,

\footnotetext{
${ }^{4}$ Moreover, according to Foster et al. (2006), productivity gains in retailing have been due almost exclusively to the entry and exit process. Caves (1998) also reports that, although entrants exhibit size heterogeneity at the time of entry, entry and exit are concentrated in the smallest size classes.

${ }^{5}$ Zentes, Hilt and Domma (2007) surveys 86 retailers in Germany, Austria and Switzerland (accounting for about $50 \%$ of total retail sales in the region). It shows that direct imports by retailers accounted for $26-29 \%$ of total sourcing in 2006 . Indirect imports accounted for $35-37 \%$ of total sourcing and hence roughly half of total domestic sourcing.
} 
searching for suppliers, developing products, specifying product standards, training suppliers, and monitoring quality. ${ }^{6}$ Evidence from Canadian retailing also suggests that it is the large retailers that carry out the lion's share of direct importing. In NAICS 4481-83 (Clothing, Shoes, Jewellery, Luggage and Leather Goods), for example, retail establishments with 50 employees or more account for $76.3 \%$ of direct imports from low-cost Asian countries. ${ }^{7}$

Our paper is linked to the literature in the following way. Retail markets have been investigated by Campbell and Hopenhayn (2005) who show that establishments tend to be larger in larger markets. They also suggest that dispersion of establishment sizes is well approximated by a Pareto distribution. The role of international trade on retailers has been analyzed by Basker and Van (2008a) who investigate the effects of trade liberalization on competition between a chain retailer and small single-market retailers. They find that trade liberalization raises the size of the chain retailer, and that the growth of the chain gives an additional boost to imports. However, their paper is silent about changes in the mass and size distribution of retailers, pass-through, and about welfare effects.

Other papers examining the interaction between trade liberalization and retail market structure include Raff and Schmitt (2008) who study the effects of trade liberalization in an oligopoly model with buyer power; Eckel (2008) who examines the effects of trade on retail market structure and especially on product diversity and accessibility of retailers; Francois and Wooton (2008) who show that market structure in distribution becomes increasingly important for trade as tariffs fall; and Richardson (2004) who studies market access to retail distribution. Another related paper is by Javorcik, Keller and Tybout (2006) who examines the effect of NAFTA on the Mexican soaps, detergents and surfactant industry. They argue that these effects were less due to the reduction in trade costs or to the entry of foreign manufacturers

\footnotetext{
${ }^{6}$ Buying offices can indeed be quite large. For instance, KarstadtQuelle AG, Germany's biggest apparel and sixth-largest food retailer, operated 23 buying offices with a total of 1,100 employees before re-organizing its direct importing business in 2006 (Zentes, Hilt and Domma, 2007). Another survey (Foreign Trade Association, 2002, p. 9) of 23 European apparel and textile retailers with combined turnover of around $€ 138$ billion cites the "sheer number of people involved, from Buying Departments to Sourcing Offices to suppliers...who need to exchange real time information..."

${ }^{7}$ The shares in NAICS sector 4431 (Electronics and Appliances), NAICS sector 4441 (Building Material and Supplies), and NAICS 4511-12 (Sporting Goods, Hobby, Musical Instruments, Books, Periodicals, Music) are $68.2 \%, 64.1 \%$ and $67.6 \%$, respectively. Source: Statistics Canada, Import Register, Catalogue R007009, 2005.
} 
than to 'the fundamental change in relationship' between manufacturers and retailers once Walmex (Wal-Mart of Mexico) entered the market.

In the pass-through literature the papers most closely related to ours are by Hellerstein (2008) and Francois, Manchin and Norberg (2008). Hellerstein bases her empirical study of pass-through on a model with Bertrand oligopolies at both the manufacturing and retailing level. Like in our paper, this set-up generates endogenous mark-ups. However, unlike in our model, market structure remains fixed. Francois, Manchin and Norberg also work in an oligopoly framework but with representative firms and empirically examine pass-through of tariff and exchange-rate changes into producer and consumer prices using EU data.

Bertrand and Kramarz (2002) discuss the effects of retail market regulation in France, while Haskel and Sadun (2009) study the effect of regulation on the productivity of UK retailing. Schivardi and Viviano (2008) and Miyagiwa (1993) examine the impact of retail market regulations in Italy and Japan, respectively. Except for the latter paper, this literature is not concerned with the effects of regulations on international trade. Miyagiwa (1993) does not consider market structure effects of retail regulations.

The paper continues as follows. In Section 2, we present a simple model of international trade with heterogeneous retailers. The equilibria of the model and comparative static results for marginal changes in trade costs are derived in Section 3. In Section 4 we use the model to study the pass-through of import prices into retail prices and the effect of retail market regulation. In Section 5 we use simulations to assess the impact of trade liberalization on retailer concentration and social welfare both for the case with and without retail market regulation. Section 6 concludes, and the Appendix contains proofs.

\section{The Model}

In this section, we develop a simple model of a retailing sector that sources the goods it distributes both domestically and abroad. There is a continuum of retailers selling only in their domestic market (their services are nontraded). From the consumer's point of view, the products sold by different retailers are differentiated varieties. This could be because each retailer sells a different bundle of goods, or because the retailers themselves are differentiated. Retailer differentiation occurs when consumers value different retailer 
characteristics, such as location or customer services. It is more natural to interpret our model as one of retailer differentiation. We index retailers by $i \in \Omega$, and assume that all consumers share the same utility function:

$$
U=\alpha \int_{i \in \Omega} q_{i}^{c} d i-\frac{1}{2} \beta \int_{i \in \Omega}\left(q_{i}^{c}\right)^{2} d i-\frac{1}{2} \gamma\left(\int_{i \in \Omega} q_{i}^{c} d i\right)^{2}+y,
$$

where $q_{i}^{c}$ denotes the quantity per capita bought from retailer $i$, and $y$ the consumption of the numeraire good. Parameter $\beta$ describes the degree of substitutability between retailers. If $\beta=0$, retailers are perfectly substitutable, and consumers care only about their total consumption level, $Q^{c}=\int_{i \in \Omega} q_{i}^{c} d i$. The degree of differentiation between retailers increases with $\beta$.

Assuming that the demand for the numeraire product is positive, the inverse per-capita demand faced by each retailer $i$ is

$$
p_{i}=\alpha-\beta q_{i}^{c}-\gamma Q^{c} .
$$

Denoting by $L$ the number of consumers and by $N$ the mass of active retailers, the market demand faced by retailer $i$ can be expressed as a function of the average retail price $\bar{p}$ :

$$
q_{i}\left(p_{i}\right) \equiv L q_{i}^{c}=\frac{\alpha L}{\gamma N+\beta}-\frac{L}{\beta} p_{i}+\frac{\gamma N}{\gamma N+\beta} \frac{L}{\beta} \bar{p},
$$

where

$$
\bar{p}=\frac{1}{N} \int_{i \in \Omega^{*}} p_{i} d i
$$

and where $\Omega^{*}$ is the set of active retailers.

Labor, the only factor of production, is inelastically supplied and perfectly mobile between the production and the retailing sectors. Since the numeraire good is produced by a competitive industry under constant returns technology and a unit labor requirement of one, the price of labor in the economy is also equal to one. All costs are therefore expressed in terms of labor requirements.

We assume that retailers first decide wether to enter the market and thus whether to incur the sunk cost $F_{E}$. Upon entering, each retailer learns about its specific level of marginal retailing cost $c$ or, equivalently, its productivity $1 / c$. We assume that the distribution of $c$ is given by $G(c)$ with support on $\left[0, c_{M}\right]$. Since the entry cost is sunk, only entrants able to cover their marginal cost are active in the market. All remaining entrants are inactive, 
i.e., do not buy or sell any goods. Assuming that retail productivity follows a Pareto distribution, we let the cumulative distribution function for $c$ be

$$
G(c)=\left(\frac{c}{c_{M}}\right)^{k}
$$

where $k \geq 1$. When $k=1$, the distribution is uniform on $\left[0, c_{M}\right]$. As $k$ increases, the distribution shifts toward high marginal costs.

Once a retailer has entered the market, he has to decide whether to source goods domestically or to import them. Imports involve a per-unit trade cost $t$ and a fixed cost $F_{I}$. This fixed cost includes the cost of maintaining buying offices, cooperating with foreign partners to source goods, acquiring information, etc. Production (domestic or foreign) involves no fixed or sunk cost but foreign production is assumed to be cheaper than domestic production. For simplicity, we normalize the marginal cost of foreign producers to zero, and denote the marginal cost of domestic production by $w>0$.

Hence, active retailers that buy domestically maximize

$$
\left(p_{i}-c-w\right) q_{i}\left(p_{i}\right)
$$

whereas active retailers relying on imports maximize

$$
\left(p_{i}-c-t\right) q_{i}\left(p_{i}\right)-F_{I} .
$$

Below we let superscript $D$ indicate domestic sourcing, and $I$ indicate imports. $^{8}$

Taking the mass of active retailers $N$ and average retail price $\bar{p}$ as given when setting their price, it is easy to check that the profit-maximizing markups

\footnotetext{
${ }^{8}$ We may also interpret the good sold by retailers as a composite consumer good $q$ that consists of a domestic good $(z)$, and a good $(m)$ that may either be imported or sourced domestically. Equations (4) and (5) and the rest of the analysis are unchanged if one makes the following assumptions. Let goods $z$ and $m$ be aggregated according to the following CES function $q=\left(z^{\phi}+m^{\phi}\right)^{\frac{1}{\phi}}$ with $0<\phi<1 ; z$ and $m$ are hence imperfect substitutes with an elasticity of substitution equal to $\sigma=1 /(1-\phi)$. Let the marginal cost of $z$ be equal to one. A retailer can source good $m$ in two ways: First, he may buy it domestically at price $\omega$; this is mode $D$. Second, the retailer may choose direct importing. This strategy involves a fixed cost of importing, $F_{I}$, and a variable cost (including the trade cost) $\tau<\omega$. This is mode $I$. The marginal cost of the composite good $q$ is hence $w \equiv\left(1+\omega^{\frac{\phi}{\phi-1}}\right)^{\frac{\phi-1}{\phi}}$ in mode $D$, and $t \equiv\left(1+\tau^{\frac{\phi}{\phi-1}}\right)^{\frac{\phi-1}{\phi}}$ in mode $I$.
} 
must satisfy

$$
\left(p_{i}^{D}-c-w\right)=\frac{\beta}{L} q_{i}\left(p_{i}^{D}\right) \text { and }\left(p_{i}^{I}-c-t\right)=\frac{\beta}{L} q_{i}\left(p_{i}^{I}\right) .
$$

Retailer $i$ 's profit-maximizing prices when buying from domestic (foreign) sources are respectively,

$$
p_{i}^{D}=\frac{1}{2}\left(c+w+\frac{\beta \alpha+\gamma N \bar{p}}{\gamma N+\beta}\right) \text { and } p_{i}^{I}=\frac{1}{2}\left(c+t+\frac{\beta \alpha+\gamma N \bar{p}}{\gamma N+\beta}\right) .
$$

Defining $c_{D} \equiv \frac{\beta \alpha+\gamma N \bar{p}}{\gamma N+\beta}-w$, the equilibrium prices and outputs of a retailer with marginal cost $c$ are

$$
\begin{aligned}
p^{D}(c) & =w+\frac{1}{2}\left[c_{D}+c\right] ; \\
p^{I}(c) & =\frac{1}{2}\left[c_{D}+w+c+t\right] ; \\
q^{D}(c) & =\frac{L}{2 \beta}\left(c_{D}-c\right) ; \\
q^{I}(c) & =\frac{L}{2 \beta}\left(c_{D}+w-c-t\right) ;
\end{aligned}
$$

and profits are

$$
\begin{aligned}
\pi^{D}(c) & =\frac{L}{4 \beta}\left(c_{D}-c\right)^{2}-F_{E} \\
\pi^{I}(c) & =\frac{L}{4 \beta}\left(c_{D}+w-c-t\right)^{2}-F_{E}-F_{I} .
\end{aligned}
$$

Only retailers with marginal costs less than or equal to $c_{D}$ will remain active, because only they will be able to cover their marginal cost. Active retailers have to select from which source to buy their goods. A retailer is indifferent between domestic sourcing and direct imports if $\pi^{D}(c)=\pi^{I}(c)$ This condition defines a critical value of the marginal cost $c_{I}$,

$$
c_{I}=c_{D}+\frac{(w-t)}{2}-\frac{2 \beta F_{I}}{L(w-t)},
$$

such that firms with $c \leq c_{I}$ prefer imports and firms with $c>c_{I}$ domestic sourcing. We assume that $c_{I} \leq c_{D}$ so that the least efficient active retailers weakly prefer domestic sourcing. This implies that

$$
\frac{L}{4 \beta}(w-t)^{2} \leq F_{I}
$$


We also assume that importing is more profitable for the most efficient retailers than domestic sourcing. Thus, at $c=0$, we require

$$
F_{I}<\frac{L}{4 \beta}\left((w-t)^{2}+2 c_{D}(w-t)\right)
$$

These two assumptions together with the quadratic form of the profit function ensure that the value of $c_{I}$ solving (12) is unique.

The two cut-off values of the marginal cost, $c_{D}$ and $c_{I}$, define three categories of retailers. Retailers whose marginal cost is sufficiently small $\left(c \leq c_{I}\right)$ import; retailers whose marginal costs are in the middle range $\left(c_{I}<c \leq c_{D}\right)$ source goods domestically; and retailers with high marginal costs $\left(c>c_{D}\right)$ are not active because they are not able to cover their marginal costs.

Given these cutoffs we can compute the average retail price of active retailers as

$$
\bar{p}=\frac{1}{G\left(c_{D}\right)}\left(\int_{0}^{c_{I}} p^{I}(c) d G(c)+\int_{c_{I}}^{c_{D}} p^{D}(c) d G(c)\right) .
$$

Since the marginal active retailer is just indifferent between buying and not buying, we have $q^{D}\left(c_{D}\right)=0$ and $p^{D}\left(c_{D}\right)=w+c_{D}$. Using this price in (3), the mass of active retailers can be calculated as

$$
N=\frac{\beta\left(\alpha-w-c_{D}\right)}{\gamma\left(w+c_{D}-\bar{p}\right)}
$$

The mass of active retailers is related to the mass of entrants into the retail market, $N_{E}$, by the condition $N=N_{E} G\left(c_{D}\right)$. In equilibrium the mass of entrants has to be large enough so that the expected profit of a retailer is equal to zero:

$$
\int_{0}^{c_{I}} \pi^{I}(c) d G(c)+\int_{c_{I}}^{c_{D}} \pi^{D}(c) d G(c)+\int_{c_{D}}^{c_{M}}\left(-F_{E}\right) d G(c)=0 .
$$

\section{Equilibrium and Comparative Statics}

In this section we characterize the equilibrium of the model and examine the comparative statics with regard to changes in the trade cost $t$. The endogenous variables of the model are $\bar{p}, c_{D}, c_{I}$ and $N$. The equilibrium values of these variables are given by equations (12), (15), (16) and (17). 
Consider first the zero-profit condition (17). The partial derivative of this condition with respect to $c_{I}$ is zero since, by definition, $\pi^{I}\left(c_{I}\right)=\pi^{D}\left(c_{I}\right)$. Total differentiation of this equation hence yields $d c_{D} / d t$. We can then derive $d c_{I} / d t$ from (12), and the marginal change in $\bar{p}$ from (15).

We obtain the following comparative static results:

Proposition 1 Trade liberalization (i) forces the least efficient retailers to become inactive ( $c_{D}$ decreases); (ii) induces some retailers to switch to buying imports $\left(c_{I}\right.$ rises); and (iii) reduces the average consumer price $\bar{p}$.

Proof: see Appendix.

The intuition for these effects is as follows. A reduction in the trade cost, ceteris paribus, raises the profits of importers both in absolute terms and relative to those retailers that source their goods domestically. Hence more retailers will turn to imports ( $c_{I}$ rises). To keep the zero-profit condition satisfied ex ante despite the fact that active retailers will ex post earn a larger profit, $c_{D}$ has to decrease so as to lower the probability of being an active retailer.

To explain the effect on $\bar{p}$ we apply the Pareto distribution to (15), which yields

$$
\bar{p}=w+\frac{k c_{D}}{k+1}+\frac{c_{D}}{2(k+1)}-\frac{(w-t)}{2} \frac{c_{I}^{k}}{c_{D}^{k}} .
$$

The four terms of this expression have a natural interpretation: the first term is, of course, the marginal cost of domestic production; the second term is the expected marginal cost of retailing conditional on $c<c_{D}$ (i.e., $\left.\frac{1}{G\left(c_{D}\right)} \int_{0}^{c_{D}} c d G(c)\right)$; the third term is the expected markup of retailers sourcing domestically $\left(c_{D}-c\right) / 2$ conditional on $c<c_{D}$ (i.e., $\frac{1}{G\left(c_{D}\right)} \int_{0}^{c_{D}} \frac{1}{2}\left(p^{D}-\right.$ c) $d G(c)$ ); and the last term is equal to the fraction of cost savings from imports that is passed on to consumers, $(w-t) / 2$, times the probability of being an importer conditional on $c<c_{D}$.

A reduction in $t$ directly affects the last term in (18): there are greater savings from imports relative to domestic sourcing, and the probability of importing rises. Indirect effects arise as trade liberalization eliminates the least efficient retailers. As can be seen from the second and third terms in (18), a decrease in $t$ lowers the expected marginal retail cost, and reduces the mark-up of retailers buying goods domestically.

Since the retail sector is imperfectly competitive, retailers that source their goods from abroad pass only part of the reduction in trade costs on to 
consumers. Their mark-ups, sales and profits hence rise. Retailers that buy their goods domestically, on the other hand, are forced to cut their mark-ups, which leads to lower sales and profits. These effects can be summarized as follows:

Proposition 2 Trade liberalization (i) lowers the sales, mark-ups and profits of retailers that source domestically; (ii) raises the sales, mark-ups and profits of retailers that engage in direct imports.

Proof: see Appendix.

Firms respond to changes in expected profits by entering or exiting the retail sector. Propositions 1 and 2 indicate that trade liberalization indeed induces changes in expected profits. First, since trade liberalization reduces $c_{D}$, the likelihood of earning a positive operating profit, $G\left(c_{D}\right)$, falls. Second, the profit earned by an importer rises and, since $c_{I}$ goes up, so does the probability of being an importer. Third, the profit of a retailer buying goods domestically decreases, but so does the probability of falling into this category.

We can use (16) to derive how the mass of active firms $N$ changes with marginal changes in $t$, keeping in mind that $N$ is related to the equilibrium mass of entrants $N_{E}$ via the condition $N=N_{E} G\left(c_{D}\right)$ :

$$
\frac{d N}{d t}=\frac{\beta}{\gamma\left(w+c_{D}-\bar{p}\right)^{2}}\left(-(\alpha-\bar{p}) \frac{d c_{D}}{d t}+\left(\alpha-w-c_{D}\right) \frac{d \bar{p}}{d t}\right) .
$$

The first expression in parentheses represents the cost effect: a fall in $t$ reduces the average retail cost and thus implies a higher number of active retailers. The second expression represents the price effect: a decrease in $t$ reduces the average retail price, which drives down the number of active retailers. The sign of $\frac{d N}{d t}$ is therefore generally ambiguous, that is, it depends very much on the characteristics of the retail sector. However, we can prove:

Proposition 3 Trade liberalization reduces the mass of active retailers if the fixed cost of importing is sufficiently small and the market (as measured by a) is sufficiently big.

Proof: see Appendix.

Before studying pass-through and the impact of regulation, it is important to point out that the analysis above does not only apply in the long run when 
there is free entry and exit of retailers, but also in the short run when $N_{E}$ is fixed. The reason is that the selection effect also works in the short run as retailers can very quickly add or drop product lines (i.e. become active or inactive), or change their sourcing strategies.

In the short run, the equilibrium values of $\bar{p}, c_{D}$ and $c_{I}$ are given by Equations (15), (12) and (16), where in the latter equation we substitute for $N$ using $N=N_{E} G\left(c_{D}\right)$. We show in the Appendix that the effect of $t$ on the equilibrium values of these variables is qualitatively the same as in the long run when free entry and exit drive expected retail profits to zero.

\section{Pass-Through and Retail Market Regula- tion}

Our model of retail market structure is admittedly highly stylized. However, it is precisely its simplicity that allows us to investigate two issues in which the structure of retail markets plays a key role. The first issue concerns the pass-through of import prices into retail prices. We want to show that passthrough may be high if one takes into account that retailers may switch the sourcing of their goods. The second issue concerns the effects of retail-market regulations, such as limits on the size of retail establishments as traditionally imposed in France, Belgium, Japan, Italy, the U.K. and elsewhere. We will show that such regulations tend to raise average retail prices and reduce pass-through.

\subsection{Pass-Through of Import into Retail Prices}

The pass-through of changes in the import price $t$ into the average retail price $\bar{p}$ can be studied using (18). As is evident from this equation, changes in $t$ have a direct effect on $\bar{p}$, as well as indirect effects through changes in the equilibrium values of $c_{D}$ and $c_{I}$. Specifically, the pass-through rate for the average retail price can be written as

$$
\frac{d \bar{p}}{d t}=\frac{1}{2} \frac{c_{I}^{k}}{c_{D}^{k}}+\frac{k}{k+1} \frac{d c_{D}}{d t}+\frac{1}{2(k+1)} \frac{d c_{D}}{d t}+\frac{(w-t)}{2} \frac{c_{I}^{k}}{c_{D}^{k}}\left(\frac{k}{c_{D}} \frac{d c_{D}}{d t}-\frac{k}{c_{I}} \frac{d c_{I}}{d t}\right) .
$$

The first term is the standard pass-through effect: the share of direct cost savings that an importer passes on to consumers $(1 / 2)$ times the probability 
that a good is being imported. This effect is clearly less than one and may be very small if the probability that a good is imported (or, equivalently, the share of imports in the consumption basket) is small. This probability depends in a straightforward way on the trade cost. It also depends on the distribution of retailing costs as summarized by parameter $k$.

The last three terms in (20) reflect the fact that trade liberalization (i) changes retailing costs and retail markups as the least efficient retailers become inactive, and (ii) increases the likelihood that a good is being sourced from abroad. Specifically, the second term reflects the fact that a reduction in $t$ lowers the expected unit cost of retailing. The third term indicates that a lower $t$ reduces the markup of domestically sourced goods. The fourth term shows that trade liberalization, by raising the probability of importing, generates cost savings from importing for a bigger share of the consumption basket.

Since the last three effects are positive, the pass-through rate may be big even if the first term is small. How big it is depends in part on the level of trade cost. We are able to show the following surprising result:

Proposition 4 The rate of pass-through of import prices into the average retail price may exceed unity.

Proof: see Appendix.

The proof of the proposition shows that a sufficient condition for this result to hold is that there is a large enough proportion of retailers that source their goods from abroad (e.g., a sufficiently low fixed cost of importing). This result demonstrates that an analysis of pass-through that is limited to the standard effect, i.e., the share of cost savings that retailers sourcing goods from abroad pass on to consumers times the import share in the retail sector, may severely underestimate the actual pass-through.

It is important to notice that Proposition 4 is not inconsistent with relatively low rates of pass-through with respect to either the average retail price of imported products, $\bar{p}^{I}$, or the average retail price of domestic products, $\bar{p}^{D}$. To see this, note that a change in $t$ has a larger impact on the average retail price of imported products than on the average retail price of domestic products (i.e., $d \bar{p}^{I} / d t>d \bar{p}^{D} / d t$ ). Simply, the latter price reacts indirectly because of the competition among retailers, while the former price also reacts directly to a change in $t$. But how do these two rates compare to the passthrough rate with respect to the average retail price, $d \bar{p} / d t$ ? Interestingly, 
in our model we have $d \bar{p} / d t>d \bar{p}^{I} / d t>d \bar{p}^{D} / d t$ at least for low values of $t$ because the change in the composition of products (imported versus domestic) is taken into account in the first rate but not in the two others. Figure 1 illustrates the point. It represents the retail price of imports (over $\left[0, c_{I}\right]$ ) and the retail price of the domestic products (over $\left[c_{I}, c_{D}\right]$ ) given an arbitrary value of $t$. As trade is liberalized, the retail price of imports falls and some retailers switch from domestic to foreign sourcing $\left(c_{I}\right.$ rises to $\left.c_{I}^{\prime}\right)$, while some small retailers selling domestic products become inactive $\left(c_{D}\right.$ falls to $\left.c_{D}^{\prime}\right)$. By definition, the pass-through rate with respect to the average retail price of imports depends on how the average retail price over the new set of imports changes relative to the average retail price over the initial set of imports. Similarly for the pass-through rate with respect to the average retail price of domestic products. There is no reason why these rates should be large as higher-cost retailers are added to the existing mix of firms selling imports, while lower-cost retailers (but also some higher-cost retailers) are dropped from the mass of firms selling domestic products. By also including the switch in sourcing from domestic products to imports, and thus significant decreases in retail prices over the interval A-B in Figure 1, the pass-through rate for the average retail price is higher than the one for imports and domestic products. It is, in fact, easy to find examples where the pass-through rate for the average retail price is above one but where the pass-through rates for the average retail price of domestic and for foreign products are both below one. This also implies that Proposition 4 is not inconsistent with existing results (see, for instance Campa and Goldberg, 2006b, Table 5).

The fact that an overall pass-through rate greater than one is not inconsistent with pass-through rates with respect to retail prices of imported and domestic products that are lower than one points to the importance of including changes in retail costs and markups spurred by the elimination of inefficient retailers and the increase in foreign sourcing into the computation of the pass-through rate. Only if one takes into account these key adjustment and composition effects associated with a change in trade costs (or more generally permanent external shocks) does one obtain an unbiased estimate of the pass-through rate. Interestingly, this also indicates that there may not be inconsistencies between low observed pass-through rates and significant impacts on consumers from import penetration. 


\subsection{Retail-Market Regulation}

A regulation limiting the size of retail establishments only affects the very efficient retailers. In effect, such a regulation can be thought of as putting an upper bound on their sales. Suppose the maximum level of sales allowed under the regulation is given by $\hat{q}$. Using $\hat{q}$ in (3) and the definition of $c_{D}$, we obtain the price charged by a constrained firm, $\hat{p}$, as

$$
\hat{p}=c_{D}+w-\frac{\beta}{L} \hat{q} .
$$

Assuming that the marginal firm that is just constrained in its sales is an importer, we can write the profit of a constrained firm as

$$
\hat{\pi}(c)=\left(c_{D}+w-\frac{\beta}{L} \hat{q}-c-t\right) \hat{q}-F_{E}-F_{I} .
$$

The critical value of the marginal cost $\hat{c}$ at which a firm is just constrained is defined by $\hat{q} \equiv q^{I}(\hat{c})$. Hence

$$
\hat{c}=c_{D}+w-t-\frac{2 \beta}{L} \hat{q} .
$$

At this level of marginal cost we have $\hat{\pi}(\hat{c})=\pi^{I}(\hat{c})$.

Ceteris paribus, a tightening of the constraint raises $\hat{c}$, which implies that the sales constraint hits even less efficient firms. Of course a change in $\hat{q}$ also affects the other critical levels of the marginal cost, i.e., $c_{D}$ and $c_{I}$, together with the other endogenous variables, $\bar{p}$ and $N_{E}$. The long-term equilibrium values of the endogenous variables when the constraint is binding are given by equations (16), (12) and (23), as well as the new expected-zero-profit condition

$$
\int_{0}^{\hat{c}} \hat{\pi}(c) d G(c)+\int_{\hat{c}}^{c_{I}} \pi^{I}(c) d G(c)+\int_{c_{I}}^{c_{D}} \pi^{D}(c) d G(c)+\int_{c_{D}}^{c_{M}}\left(-F_{E}\right) d G(c)=0,
$$

and the new equation for the average retail price

$$
\overline{\hat{p}}=\frac{1}{G\left(c_{D}\right)}\left(\int_{0}^{\hat{c}} \hat{p} d G(c)+\int_{\hat{c}}^{c_{I}} p^{I}(c) d G(c)+\int_{c_{I}}^{c_{D}} p^{D}(c) d G(c)\right)
$$

To derive the comparative static effects of a marginal change in the constraint $\hat{q}$, consider again the zero-profit condition. Since, by definition, 
$\hat{\pi}(\hat{c})=\pi^{I}(\hat{c})$ and $\pi^{I}\left(c_{I}\right)=\pi^{D}\left(c_{I}\right)$, the partial derivatives of (24) with respect to $\hat{c}$ and $c_{I}$ are zero. We therefore directly obtain from (24) the change in $c_{D}$ for marginal changes in $\hat{q}$. The respective changes in $\hat{c}$ and $c_{I}$ then follow directly from (23) and (12). The following proposition presents these comparative-static effects:

Proposition 5 A tightening of the sales constraint $\widehat{q}$ : (i) allows less efficient retailers to become active ( $c_{D}$ rises); (ii) reduces the sales of more efficient retailers ( $\hat{c}$ rises); and (iii) induces some retailers to source goods from abroad ( $c_{I}$ rises $)$.

Proof: see Appendix.

Parts (i) and (ii) of the proposition are straightforward. A tighter constraint on the sales of the most efficient retailers raises the residual demand for the unconstrained retailers. This allows the least efficient retailers to remain in business. The surprising result is in part (iii), namely that a tighter sales constraint raises retailers' propensity to import. The reason for this is that the higher residual demand allows retailers that before were too inefficient to import to source their goods from abroad. This increase at the extensive margin of imports is, of course, offset by a decrease at the intensive margin: a tighter constraint reduces the import volume of efficient retailers.

To determine the effect of a tighter constraint on the average retail price, we simplify (25) to obtain

$$
\overline{\hat{p}}=w+\frac{k c_{D}}{k+1}+\frac{c_{D}}{2(k+1)}-\frac{(w-t)}{2} \frac{c_{I}^{k}}{c_{D}^{k}}+\frac{\hat{c}}{2(1+k)} \frac{\hat{c}^{k}}{c_{D}^{k}} .
$$

This first four terms of this equation are the same as in (18). The fifth term is an additional term reflecting the direct effect of the output constraint. It represents the extra expected markup of a constrained firm times the probability that a firm is constrained conditional on its cost being less than $c_{D}$.

The change in the average retail price induced by a tighter constraint comes from changes in the cut-off values $\hat{c}, c_{D}$ and $c_{I}$. A tighter $\hat{q}$ raises all three cut-off values. This has the following implications. An increase in $\hat{c}$ means that a larger fraction of retailers becomes constrained and thus has higher prices than without the constraint. The increase in $c_{D}$ also raises $\overline{\hat{p}}$, since at the margin less efficient retailers remain active in the market. The 
rise in $c_{I}$ works against the first two effects. Retailers are more likely to source goods from abroad, which is associated with lower variable costs than sourcing goods domestically. One would expect that the first two effects dominate the last one, so that a tightening of the sales constraint raises the average retail price. Formally, we can show that it is indeed the case if either $w-t$ is big and/or $F_{I}$ is small so that the retailers switching to importing have a relatively high unit retailing cost compared with the rest of the industry and thus have only a small market share.

We formally state these sufficient conditions in the following proposition:

Proposition 6 A tightening of the sales constraint $\widehat{q}$ raises the average retail price $\overline{\hat{p}}$ if $w-t$ is sufficiently big and/or $F_{I}$ is sufficiently small.

Proof: see Appendix.

Retail-market regulation also affects the pass-through of import into consumer prices. As can be seen in (21), the prices of constrained retailers are not affected at all by the import price, even though we assumed that these retailers do in fact import their goods. The reason for this is that the sales of these firms are below the level at which marginal revenue equals marginal cost, so that small changes in marginal cost have no effect on sales or prices.

In the extreme case where the constraint is so restrictive that it affects all importing firms, the pass-through into the average retail price is therefore zero even if the import share in the total consumption basket of households is large. It follows that for a sufficiently tight constraint, i.e., for $\widehat{q}$ sufficiently close to $q^{I}\left(c_{I}\right)$, the pass-through rate will be lower than without the regulation. Thus, even if retail-market regulation induces a larger mass of retailers to source from abroad, its impact on the most efficient retailers makes the average retail price less sensitive to variations in import prices. This result can be summarized as follows:

Proposition 7 Retail-market regulation reduces the rate of pass-through of import prices into the average retail price if the output constraint is sufficiently tight.

\section{Retail Market Concentration and Welfare}

In this section we use simulations to illustrate how trade liberalization impacts social welfare, as well as retail concentration and pass through. 
In the context of the present model, the Herfindahl index, $H$, is an ideal measure of market concentration. This is because this index takes into account the entire size distribution of the retailing sector and thus both the mass of active retailers as well as the dispersion of retailer size. Indeed, the Herfindahl index, defined as the sum of the squares of all retailers' market shares, can be re-written as (see Waterson, 1984)

$$
H=\frac{\sigma_{q}^{2} / \bar{q}^{2}+1}{N}
$$

where $\bar{q}$ denotes average sales of active retailers and $\sigma_{q}^{2}$ is the variance of retail sales. This formulation of $H$ reveals the separate effects on concentration stemming from the mass of retailers and from the impact of retailers' heterogeneity. Thus, in a market with heterogeneous firms, market concentration as measured by the Herfindahl index is negatively related to the mass of active retailers, $N$, and positively related to the coefficient of variation of retail sales, $\sigma_{q} / \bar{q}$. Since $0 \leq H \leq 1$, industry concentration is high if a few big retailers account for a large fraction of sales.

Another advantage of $H$ is that it can be used for policy purposes, be it for competition policy or market regulation. For example, the purpose of the retail regulations analyzed in the previous section can be interpreted as controlling retail concentration and thus reaching a lower value of $H$ than market forces alone would generate.

In addition to measuring concentration, we also want to evaluate social welfare. Social welfare in the current model is captured by the following indirect utility function (see Melitz and Ottaviano, 2008):

$$
U=I+\frac{1}{2}\left(\gamma+\frac{\beta}{N}\right)^{-1}(\alpha-\bar{p})^{2}+\frac{1}{2} \frac{N}{\beta} \sigma_{p}^{2},
$$

where $\sigma_{p}^{2}$ denotes the variance of retail prices. Welfare is obviously decreasing in $\bar{p}$ and increasing in $N$ and $\sigma_{p}^{2}$.

It is often presumed that if an exogenous shock such as trade liberalization occurs, then $H$ should fall and $U$ increase. This presumption rests on the idea that a decrease in $H$ is associated with an increase in competition and thus with a smaller social deadweight loss. It is easy to see that such a simple one-to-one relationship between $H$ and $U$ does not necessarily exist in the present model. Even if it is the case that an increase in $N$ raises $U$ and decreases $H$, heterogeneity also plays an important role. Observe in 
particular that $H$ and $U$ are increasing in $\sigma_{q}^{2}$ and $\sigma_{p}^{2}$, respectively. Thus if $d \sigma_{q}^{2} / d t$ and $d \sigma_{p}^{2} / d t$ are both positive, trade liberalization reduces $\sigma_{q}^{2}$ and $H$, and it also reduces $\sigma_{p}^{2}$ and $U$, holding fixed the values of the other endogenous variables. In the Appendix, we show that $d \sigma_{q}^{2} / d t$ and $d \sigma_{p}^{2} / d t$ are indeed both positive, at least when $F_{I}$ is small. Thus, unless trade liberalization changes the mass of retailers in a way that clearly dominates its effects on the size variation of retailers, it is quite possible that social welfare may increase, even if liberalization increases retail market concentration. Clearly, retailer heterogeneity plays a key role in this seemingly contradictory message provided by $H$ and by social welfare.

Table 1 illustrates this case. Both welfare (measured by $U$ net of income $I$ ) and $H$ monotonically rise with trade liberalization. Note that welfare increases despite a decrease in the number of active retailers, $N .^{9}$ This occurs because the average price, $\bar{p}$, falls a lot as trade costs come down. This is shown by the last column of Table 1 where the degree of pass through is greater than one, except when $t$ is high. This decrease in $N$ naturally contributes to explain why $H$ rises with trade liberalization, but so is the increase in the variance of sales, $\sigma_{q}^{2}$, and thus the degree of heterogeneity among retailers.

Table 1: $\left(L=5, F_{E}=.02, F_{I}=.1, w=.25, c_{M}=5, \alpha=1.75, \beta=.9\right.$, $\gamma=.6, k=1)$

$\begin{array}{ccccccccc}t & c_{D} & c_{I} & \bar{p} & N & \sigma_{q}^{2} & H & U-I & d \bar{p} / d t \\ 0 & .44 & .42 & .46 & 6.95 & .62 & .2 & 1.16 & 1.52 \\ .05 & .49 & .41 & .53 & 7.38 & .51 & .19 & 1.07 & 1.41 \\ .1 & .54 & .37 & .60 & 7.78 & .48 & .18 & .97 & 1.3 \\ .15 & .58 & .27 & .66 & 8.22 & .36 & .17 & .89 & 1.12 \\ .19 & .6 & .03 & .7 & 8.92 & .25 & .15 & .83 & .62\end{array}$

Simulations are also useful to show the effects of market regulation. We use as a benchmark a case in which, in the absence of any regulation, trade liberalization monotonically raises $U$ and lowers $H$. Table 2 illustrates this case for a parameter space identical to the one above except that now $F_{E}=.1$.

\footnotetext{
${ }^{9}$ And despite a small decrease in $\sigma_{p}^{2}$ for $t \leq .15$ (not shown in Table 1).
} 
Table 2:

$\begin{array}{ccccccccc}t & c_{D} & c_{I} & \bar{p} & N & \sigma_{q}^{2} & H & U-I & d \bar{p} / d t \\ 0 & .83 & .82 & .75 & 3.02 & .96 & .43 & .58 & 1.4 \\ .05 & .88 & .8 & .82 & 2.96 & .9 & .44 & .51 & 1.35 \\ .1 & .93 & .77 & .89 & 2.88 & .86 & .46 & .45 & 1.3 \\ .15 & .98 & .67 & .95 & 2.78 & .84 & .48 & .39 & 1.22 \\ .2 & 1.02 & .33 & 1.01 & 2.73 & .76 & .5 & .33 & .93\end{array}$

Suppose now that a regulation is in place that restricts the size of the most efficient retailers. Specifically, the most efficient retailer (with $c=0$ ) cannot have a volume of sales greater than $75 \%$ of its unconstrained freetrade volume. In the above example, this corresponds to a maximum sales volume allowed by regulation equal to $\widehat{q}^{I}(c=t=0)=1.83$. Of course, such a constraint affects more than just the most efficient retailers but it does so with a smaller relative impact, since less efficient retailers are smaller. Indeed, retailers with a volume of sales less than $\widehat{q}^{I}(c)=1.83$ are not affected at all. Table 3 shows the percentage changes with respect to the benchmark case without regulation and thus with respect to Table 2 (except for $c_{D}$ and $c_{I}$, for which we present levels).

$$
\begin{array}{ccccccccc}
\text { Table 3: } & & \overline{\widehat{p}} & \overline{\widehat{q}} & N & H & U-I & d \overline{\hat{p}} / d t \\
t & c_{D} & c_{I} & & & \\
0 & .86 & .84 & +11 \% & -16 \% & +14 \% & -28 \% & -14 \% & -44 \% \\
.05 & .91 & .83 & +9 \% & -16 \% & +13 \% & -22 \% & -15 \% & -41 \% \\
.1 & .96 & .8 & +8 \% & -16 \% & +13 \% & -19 \% & -16 \% & -39 \% \\
.15 & 1.0 & .7 & +7 \% & -15 \% & +12 \% & -17 \% & -17 \% & -43 \% \\
.2 & 1.04 & .35 & +6 \% & -15 \% & +11 \% & -16 \% & -17 \% & -85 \%
\end{array}
$$

The regulation has striking effects, especially regarding the impact of trade liberalization. It significantly increases the number of active retailers and decreases $H$ relative to the benchmark case. In this sense, the introduction of the regulation is a very successful policy. However, even if trade liberalization still leads to lower prices and a greater average volume of sales, the impact of freer trade is very much muted since the average price decreases to a much smaller extent and the average quantity sold by retailers increases much less than without the regulation. As already argued, this implies that the rate of pass through is much lower. Indeed it is now much lower than one and, in this example, more than $40 \%$ lower than without any regulation. As 
can be observed in the last column of Table 3, the rate of pass-through decreases even more for relatively high levels of $t$. This is because pass-through quickly converges to zero for high levels of $t$. Indeed, the rate of pass-through is necessarily equal to zero whenever all the retailers who choose to source their product from abroad are constrained by the regulation. The overall impact of the regulation is a much smaller increase in social welfare through trade liberalization than in the absence of such a regulation. Based on this example, it may not be very surprising that French consumers complain that they do not benefit from trade liberalization.

These simulations should be taken as illustrative but they show forcefully that one should be careful before using concentration indices such as the Herfindahl index in the presence of heterogeneous retailers as there is no simple one-to-one relationship between such an index and social welfare. This point is best illustrated by the case of regulation. While it may have achieved its objective by increasing the number of retailers and lowering $H$, it does not deliver in terms of social welfare because it mitigates competition and diminishes the impact of trade liberalization, especially the rate of pass through.

\section{Conclusions}

By focusing on retailers' total volume of sales, our model is highly stylized. However, it is precisely its simplicity that allows us to investigate how trade liberalization changes the structure of the retailing industry when retailers are heterogeneous. Because buying foreign products involves a fixed cost, only the most efficient retailers source goods from abroad. Trade liberalization is then shown to shift retail sales, mark-ups and profits toward big retailers that engage in direct imports and away from small ones that source domestically only. The consequences for retail market concentration, as measured by the Herfindahl Index, are ambiguous, however. If the fixed cost of direct imports is sufficiently small, trade liberalization raises the mean and reduces the variance of retail sales, which by itself lowers concentration; it also decreases the number of active retailers, which raises market concentration. The ambiguous effect of trade liberalization on market concentration carries over into social welfare, as the beneficial effect of the decrease in the average retail price is at least partly offset by a fall in the number of retailers.

The model provides clear predictions concerning the sensitivity of re- 
tail prices to variations in import prices and thus about the degree of passthrough at the retail level. It suggests that retailer heterogeneity plays an important role in explaining the degree of pass-through. Specifically, the model predicts that the rate of pass-through into consumer prices may be quite high, even exceeding unity when the fixed cost of importing is small. This is consistent with the existing studies on import-price pass-through, which find that pass-through is incomplete and often small. The reason simply is that changes in import prices trigger changes in the mass of active retailers and in sourcing decisions that lead to discrete jumps in the consumer prices of the affected retailers. When this is taken into account, the pass-through into the average consumer price may even exceed the pass-through into the average retail price of imports. This result is interesting because it suggests that there may not be an inconsistency between low observed pass-through rates and significant impacts on consumers from import penetration.

The model also shows that the pass-through increases when trade barriers fall. This effect has two sources: (i) a direct effect that leads retailers to import more when trade costs decrease and which naturally makes the retail prices more sensitive to changes in the trade barrier; and (ii) an indirect effect that comes from the fact that the average unit retailing cost falls as less efficient retailers become inactive or exit the market. Thus the importance of domestic retailing costs, an element that tends to isolate domestic prices from foreign influences, falls as well. The sensitivity of the retail prices also depends very much on the characteristics of the retail sector. Thus if some of these characteristics also change with trade liberalization (for instance, due to technological innovation), the rate of pass-through may well increase even more. These predictions are consistent with the empirical evidence presented, for instance, by Campa and Goldberg (2006b), and Campa and González Minguez (2006). The former paper finds that the retail price sensitivity to import price variations has generally increased over the last decade, but that the degree of sensitivity is very much product specific. The latter shows that differences in pass-through rates within the Euro area are driven mainly by differences in openness to non-Euro-area imports.

Finally, the model is also well suited to understand the impact of restrictions on the size of retailers. In countries like France, Belgium or Japan, there is a tradition of protecting small local retailers by placing barriers on the expansion and particularly on the size of large retailers. Not surprisingly, restrictions on the volume of sales affect first and foremost the efficient retailers. We show that this allows inefficient retailers to remain active and makes 
the average retail price higher than it would otherwise be. Interestingly this makes the incentives to source products from abroad stronger for less efficient retailers, not weaker. We also show that it makes the retail price level less sensitive to changes in the price of imported products. With higher average retail prices and a lower sensitivity of retail prices to foreign shocks, it should not be surprising if French consumers feel that their 'pouvoir d'achat' (purchasing power) has suffered as compared to consumers elsewhere in Europe (Economist, 2008).

The contrast with the United States is striking. Broda and Romalis (2008) show that because poor US households have a different composition of their consumption basket than rich households and because the price index of the poor's consumption basket has declined relative to that of the rich, the impact of the rise in income inequality has been significantly smaller than first feared. One thing is certain, this would not have been possible without the instrumental role played by large retailers importing a large volume of products from low-cost Asian countries.

These two examples underline well the significant impact of the retailing sector in a more integrated world. Simply put, in the United States, the large retailers seem to allow poor consumers to keep up with the Joneses whereas in France consumers feel cheated by the retailers and do not perceive much benefit from globalization. Of course much more needs to be done to understand the role and the impact of the retailing sector in today's world. This is left for future research.

\section{Appendix}

\subsection{Proof of Proposition 1}

Using the Pareto distribution, (17) can be rewritten as

$\frac{c_{D}^{k+2}}{(k+1)(k+2)}+(w-t) c_{I}^{k}\left(\frac{w-t}{2}+c_{D}-\frac{k c_{I}}{k+1}\right)-\frac{2 \beta}{L}\left(c_{M}^{k} F_{E}+F_{I} c_{I}^{k}\right)=0$.

Total differentiation of (29) yields

$$
\frac{d c_{D}}{d t}=\frac{c_{I}^{k}\left(c_{D}+w-t-\frac{k c_{I}}{k+1}\right)}{\frac{c_{D}^{k+1}}{(k+1)}+(w-t) c_{I}^{k}}>0
$$


since $\frac{c_{D}^{k+1}}{(k+1)}+(w-t) c_{I}^{k}=2 c_{D}^{k}\left(w+c_{D}-\bar{p}\right)>0$ and $w-t+c_{D}-\frac{k c_{I}}{k+1}>0$ due to $w>t, c_{D}>c_{I}$ and $k<1+k$.

From (12) we obtain

$$
\frac{d c_{I}}{d t}=\frac{d c_{D}}{d t}-\left(\frac{1}{2}+\frac{2 \beta F_{I}}{L(w-t)^{2}}\right)
$$

Substituting for $\frac{d c_{D}}{d t}$ we have

$$
\begin{array}{r}
\frac{d c_{I}}{d t}=\frac{1}{\frac{c_{D}^{k+1}}{(k+1)}+(w-t) c_{I}^{k}}\left[-\left(\frac{1}{2}+\frac{2 \beta F_{I}}{L(w-t)^{2}}\right)\right. \\
\left(\frac{c_{D}^{1+k}}{1+k}+(w-t) c_{I}^{k}\right) \\
\left.+c_{I}^{k}\left(c_{D}+w-t-\frac{k c_{I}}{1+k}\right)\right] .
\end{array}
$$

Using $\frac{2 \beta F_{I}}{L(w-t)^{2}}=\frac{1}{(w-t)}\left(c_{D}-c_{I}+\frac{w-t}{2}\right)$ (from (12)) in the above expression and simplifying, we get

$$
\frac{d c_{I}}{d t}=\frac{1}{2 c_{D}^{k}\left(w+c_{D}-\bar{p}\right)}\left\{-\frac{c_{D}^{1+k}}{1+k}\left[1+\frac{c_{D}-c_{I}}{w-t}\right]+\frac{c_{I}^{1+k}}{1+k}\right\}<0 .
$$

Note that $\frac{d c_{I}}{d t}<0$ provided $c_{D}^{1+k}\left(w-t+c_{D}-c_{I}\right)>(w-t) c_{I}^{1+k}$ which holds since $w>t$ and $c_{D}>c_{I}$.

Using (18), it is easy to check that

$$
\frac{d \bar{p}}{d t}=\left(\frac{1+2 k}{2+2 k}\right) \frac{d c_{D}}{d t}+\frac{1}{2} \frac{c_{I}^{k}}{c_{D}^{k}}+\frac{k(w-t)}{2} \frac{c_{I}^{k}}{c_{D}^{k}}\left[\frac{1}{c_{D}} \frac{d c_{D}}{d t}-\frac{1}{c_{I}} \frac{d c_{I}}{d t}\right]>0,
$$

since all the terms on the RHS are positive.

\subsection{Proof of Proposition 2}

Differentiating (8) and (10) with respect to $t$ and using (30), it is easy to check that, for retailers sourcing domestically,

$$
\frac{d q^{D}}{d t}=\frac{L}{2 \beta} \frac{d c_{D}}{d t}>0 \text { and } \frac{d \pi^{D}}{d t}=\frac{L}{2 \beta}\left(c_{D}-c\right) \frac{d c_{D}}{d t}>0 .
$$

Next, we show that $\frac{d c_{D}}{d t}<1$. Rewriting and manipulating (30),

$$
\frac{d c_{D}}{d t}=\frac{(1+k)(w-t)+c_{D}+k\left(c_{D}-c_{I}\right)}{(1+k)(w-t)+\frac{c_{D}^{1+k}}{c_{I}^{k}}} .
$$


Thus, $\frac{d c_{D}}{d t}<1$ if $c_{D}+k\left(c_{D}-c_{I}\right)<\frac{c_{D}^{1+k}}{c_{I}^{k}}$ or if $1+k\left(1-\frac{c_{I}}{c_{D}}\right)<\frac{c_{D}^{k}}{c_{I}^{k}}$. When $k=1$, this inequality reduces to $\left(c_{D}-c_{I}\right)^{2}>0$, and when $k>1$, the RHS of the above inequality increases faster than the LHS. Since $0<\frac{d c_{D}}{d t}<1$, it is easy to check that, for retailers selling imported goods,

$$
\frac{d q^{I}}{d t}=\frac{L}{2 \beta}\left[\frac{d c_{D}}{d t}-1\right]<0 \text { and } \frac{d \pi^{I}}{d t}=\frac{L}{2 \beta}\left(c_{D}+w-t-c\right)\left[\frac{d c_{D}}{d t}-1\right]<0 .
$$

\subsection{Proof of Proposition 3}

After substituting for $\bar{p}$ and $\frac{d \bar{p}}{d t}$ in (19), we have

$$
\begin{gathered}
\operatorname{sign}\left\{\frac{d N}{d t}\right\}=\operatorname{sign}\left\{\left(\frac{w-\alpha}{2+2 k}\right) \frac{d c_{D}}{d t}+\left(\frac{w-t}{2}\right) \frac{c_{I}^{k}}{c_{D}^{k}}\left(\frac{k\left(\alpha-w-c_{D}\right)}{c_{D}}-1\right) \frac{d c_{D}}{d t}\right. \\
\left.+\frac{\left(\alpha-w-c_{D}\right)}{2} \frac{c_{I}^{k}}{c_{D}^{k}}-\frac{k\left(\alpha-w-c_{D}\right)}{c_{I}} \frac{c_{I}^{k}}{c_{D}^{k}}\left(\frac{w-t}{2}\right) \frac{d c_{I}}{d t}\right\} .
\end{gathered}
$$

For $F_{I}$ equal to its lower bound (see $(13)$ ), we have $c_{D}=c_{I}, \frac{d c_{I}}{d t}=0$, and $\frac{d c_{D}}{d t}=1$. Therefore,

$\operatorname{sign}\left\{\frac{d N}{d t}\right\}=\operatorname{sign}\left\{\frac{w-\alpha}{2+2 k}+\frac{w-t}{2}\left(\frac{k\left(\alpha-w-c_{D}\right)}{c_{D}}-1\right)+\frac{\left(\alpha-w-c_{D}\right)}{2}\right\}$.

Further simplification yields:

$$
\operatorname{sign}\left\{\frac{d N}{d t}\right\}=\operatorname{sign}\left\{k\left(\alpha-w-c_{D}\right)-c_{D}\right\}
$$

Since in equilibrium $d c_{D} / d \alpha=0$ from (29), sign $\left\{\frac{d N}{d t}\right\}>0$ if $\alpha$ is sufficiently big.

\subsection{Comparative Statics for the Short Run}

Totally differentiating Equations (16), (12) and (18), and using $N=N_{E}\left(c_{D} / c_{M}\right)^{k}$, we have

$$
\left[\begin{array}{ccc}
a_{11} & a_{12} & 0 \\
0 & -1 & 1 \\
1 & a_{32} & a_{33}
\end{array}\right]\left[\begin{array}{c}
d \bar{p} \\
d c_{D} \\
d c_{I}
\end{array}\right]=\left[\begin{array}{c}
0 \\
b_{2} \\
b_{3}
\end{array}\right] d t
$$


where

$$
\begin{aligned}
& a_{11}=\frac{\beta\left(\alpha-w-c_{D}\right)}{\gamma\left(w+c_{D}-\bar{p}\right)^{2}}>0, \\
& a_{12}=-\left(\frac{\beta(\alpha-\bar{p})}{\gamma\left(w+c_{D}-\bar{p}\right)^{2}}+\frac{N_{E} k c_{D}^{k-1}}{c_{M}^{k}}\right)<0, \\
& a_{32}=-\left(\frac{1+2 k}{2(1+k)}+\frac{k(w-t) c_{I}^{k}}{2 c_{D}^{k+1}}\right)<0, \\
& a_{33}=\frac{k(w-t) c_{I}^{k-1}}{2 c_{D}^{k}}>0,
\end{aligned}
$$

and

$$
\begin{aligned}
b_{2} & =-\left(\frac{1}{2}+\frac{2 \beta F_{I}}{L(w-t)^{2}}\right)<0, \\
b_{3} & =\frac{c_{I}^{k}}{2 c_{D}^{k}}>0 .
\end{aligned}
$$

The value of the determinant is given by $|D|=-a_{11}\left(a_{32}+a_{33}\right)+a_{12}$. After some algebraic manipulation we can show that

$$
\begin{aligned}
|D|=-\frac{\beta\left(\alpha-w-c_{D}\right)}{\gamma\left(w+c_{D}-\bar{p}\right)^{2}}\left[\frac{1}{2(1+k)}+\right. & \left.\frac{k(w-t) c_{I}^{k-1}\left(c_{D}-c_{I}\right)}{2 c_{D}^{k+1}}\right] \\
& -\frac{\beta}{\gamma\left(w+c_{D}-\bar{p}\right)}-\frac{N_{E} k c_{D}^{k-1}}{c_{M}^{k}}<0 .
\end{aligned}
$$

Using Cramer's Rule, we have

$$
\begin{aligned}
\frac{d \bar{p}}{d t} & =\frac{1}{|D|}\left|\begin{array}{ccc}
0 & a_{12} & 0 \\
b_{2} & -1 & 1 \\
b_{3} & a_{32} & a_{33}
\end{array}\right| \\
& =\frac{a_{12}\left(b_{3}-a_{33} b_{2}\right)}{|D|}>0,
\end{aligned}
$$

since $|D|<0, a_{12}<0$ and $\left(b_{3}-a_{33} b_{2}\right)>0$;

$$
\begin{aligned}
\frac{d c_{D}}{d t} & =\frac{1}{|D|}\left|\begin{array}{ccc}
a_{11} & 0 & 0 \\
0 & b_{2} & 1 \\
1 & b_{3} & a_{33}
\end{array}\right| \\
& =\frac{-a_{11}\left(b_{3}-a_{33} b_{2}\right)}{|D|}>0
\end{aligned}
$$


since $|D|<0, a_{11}>0$ and $\left(b_{3}-a_{33} b_{2}\right)>0$;

$$
\begin{aligned}
\frac{d c_{I}}{d t} & =\frac{1}{|D|}\left|\begin{array}{ccc}
a_{11} & a_{12} & 0 \\
0 & -1 & b_{2} \\
1 & a_{32} & b_{3}
\end{array}\right| \\
& =\frac{a_{12} b_{2}-a_{11} b_{3}-a_{11} a_{32} b_{2}}{|D|}<0
\end{aligned}
$$

since $|D|<0$, and after some algebraic transformations

$$
\begin{aligned}
a_{12} b_{2}-a_{11} b_{3}- & a_{11} a_{32} b_{2} \\
=\frac{\beta\left(\alpha-w-c_{D}\right)}{\gamma\left(w+c_{D}-\bar{p}\right)^{2}} & \frac{1}{2}\left(\frac{c_{D}-c_{I}}{(w-t)}+1-\frac{c_{I}^{k}}{c_{D}^{k}}\right) \\
+ & \left(\frac{1}{2}+\frac{2 \beta F_{I}}{L(w-t)^{2}}\right) \frac{\beta}{\gamma\left(w+c_{D}-\bar{p}\right)}>0 .
\end{aligned}
$$

In the short run, the pass-through rate with respect to the average retail price is also given by (20); it is also easy to find examples for which the short-term pass-through rate is greater than one.

\subsection{Proof of Proposition 4}

When $c_{D}=c_{I}, \frac{d c_{I}}{d t}=0$ and $\frac{d c_{D}}{d t}=1$ (and thus when $F_{I}$ is near its lower bound as given by (13)). Using this in (20) yields

$$
\frac{d \bar{p}}{d t}=\frac{3 k+2}{2(k+1)}+\frac{k(w-t)}{2 c_{D}}>1
$$

By continuity, $d \bar{p} / d t>1$ for $F_{I}$ greater but sufficiently close its lower bound.

\subsection{Proof of Proposition 5}

Using the Pareto distribution in (24) and totally differentiating the resulting equation gives

$$
\frac{d c_{D}}{d \hat{q}}=-\frac{2 \beta \hat{c}^{k+1}}{L\left(\frac{c_{D}^{k+1}}{(k+1)}+(w-t) c_{I}^{k}\right)}<0
$$


From (23) and (12) we can then compute

$$
\begin{aligned}
\frac{d \hat{c}}{d \hat{q}} & =\frac{d c_{D}}{d \hat{q}}-\frac{2 \beta}{L}<0, \\
\frac{d c_{I}}{d \hat{q}} & =\frac{d c_{D}}{d \hat{q}}<0 .
\end{aligned}
$$

\subsection{Proof of Proposition 6}

Using (42) and (43), the derivative of (26) is

$$
\begin{aligned}
& \frac{d \overline{\hat{p}}}{d \hat{q}}=\frac{1+2 k}{2(1+k)} \frac{d c_{D}}{d \hat{q}}-\frac{k(w-t)\left(c_{D}-c_{I}\right)}{2} \frac{c_{I}^{k-1}}{c_{D}^{k+1}} \frac{d c_{D}}{d \hat{q}} \\
& +\frac{1}{2(1+k)} \frac{\widehat{c}^{k}}{c_{D}^{k}} \frac{\left(c_{D}(1+k)-k \hat{c}\right)}{c_{D}} \frac{d c_{D}}{d \hat{q}}-\frac{\beta}{L} \frac{\hat{c}^{k}}{c_{D}^{k}}
\end{aligned}
$$

Since $\frac{d c_{D}}{d \hat{q}}<0$ and $c_{D}(1+k)-k \hat{c}>0$, we have $\frac{d \overline{\hat{p}}}{d \hat{q}}<0$ if the second term is sufficiently small. Using (12), the second term can be written as:

$$
\frac{k(w-t)\left(c_{D}-c_{I}\right)}{2} \frac{c_{I}^{k-1}}{c_{D}^{k+1}} \frac{d c_{D}}{d \hat{q}}=\left(\frac{\beta F_{I}}{L}-\frac{(w-t)^{2}}{4}\right) \frac{k c_{I}^{k-1}}{c_{D}^{k+1}} \frac{d c_{D}}{d \hat{q}} .
$$

Hence, $\frac{d \overline{\hat{p}}}{d \hat{q}}<0$ provided that $F_{I}$ is small and/or $(w-t)$ is big enough.

\subsection{Average Sales and Variance of Sales}

The average sales volume of active retailers is given by

$$
\bar{q}=q(\bar{p})=\frac{L}{\beta}\left(\frac{c_{D}}{2(k+1)}+\frac{(w-t)}{2} \frac{c_{I}^{k}}{c_{D}^{k}}\right),
$$

and the derivative with respect to $t$ is

$$
\frac{d \bar{q}}{d t}=\frac{L}{2 \beta}\left((w-t) \frac{c_{I}^{k-1}}{c_{D}^{k+1}}\left(c_{D} \frac{d c_{I}}{d t}-c_{I} \frac{d c_{D}}{d t}\right)-\frac{c_{I}^{k}}{c_{D}^{k}}+\frac{1}{k+1} \frac{d c_{D}}{d t}\right) .
$$

For $F_{I}=0$, we have $c_{D}=c_{I}, \frac{d c_{I}}{d t}=0$, and $\frac{d c_{D}}{d t}=1$. Using these values in (46), we obtain

$$
\left.\frac{d \bar{q}}{d t}\right|_{F_{I}=0}=-\frac{L}{2 \beta}\left((w-t) \frac{c_{I}^{k}}{c_{D}^{k+1}}+\frac{k}{k+1}\right)<0 .
$$


The variance of retail sales is given by

$$
\begin{aligned}
\sigma_{q}^{2}= & \frac{L^{2}}{4 \beta^{2}}\left\{\frac{k c_{D}^{2}}{(k+2)(k+1)^{2}}\right. \\
& \left.+\left((w-t)^{2}\left[1-\frac{c_{I}^{k}}{c_{D}^{k}}\right]+\frac{2 k\left(c_{D}-c_{I}\right)(w-t)}{(k+1)}\right) \frac{c_{I}^{k}}{c_{D}^{k}}\right\} .
\end{aligned}
$$

Hence

$$
\left.\frac{d \sigma_{q}^{2}}{d t}\right|_{F_{I}=0}=(w-t)^{2} \frac{k}{c_{D}}+\frac{2 k c_{D}}{(k+2)(k+1)^{2}}>0 .
$$

By continuity we have $d \bar{q} / d t<0$ and $d \sigma_{q}^{2} / d t>0$ for $F_{I}$ sufficiently close to zero.

\subsection{Variance of Retail Prices}

The variance of retail prices is given by:

$$
\sigma_{p}^{2}=\frac{1}{4}\left\{\frac{k c_{D}^{2}}{(2+k)(1+k)^{2}}+\left((w-t)^{2}\left[1-\frac{c_{I}^{k}}{c_{D}^{k}}\right]+\frac{2\left(c_{D}-c_{I}\right)(w-t)}{k+1}\right) \frac{c_{I}^{k}}{c_{D}^{k}}\right\} .
$$

The proof that $d \sigma_{p}^{2} / d t>0$ for $F_{I}$ sufficiently close to zero is identical to the one for $d \sigma_{q}^{2} / d t>0$. Also note that for $k=1, \sigma_{q}^{2}=\left(L^{2} / \beta^{2}\right) \sigma_{p}^{2}$.

\section{References}

[1] Bacchetta, Philippe and Eric van Wincoop, 2003. Why do Consumers Prices React Less than Import Prices to Exchange Rates, Journal of the European Economics Association 1, 2-3, 325-52.

[2] Basker, Emek and Pham Hoang Van, 2008a. Wal-Mart as Catalyst to US-China Trade, University of Missouri, mimeo.

[3] Basker, Emek and Pham Hoang Van, 2008b. Imports "R" Us: Retail Chains as Platforms for Developing-Country Imports, University of Missouri, mimeo.

[4] Bertrand, Marianne and Francis Kramarz, 2002. Does Entry Regulation Hinder Job Creation? Evidence from the French Retailing Industry, Quarterly Journal of Economics 117, 1369-1413. 
[5] Broda, Christian and John Romalis, 2008. Inequality and Prices: Does China Benefit the Poor in America? mimeo, University of Chicago GSB.

[6] Campa, José Manuel and Linda S. Goldberg, 2006a. Distribution Margins, Imported Inputs, and the Sensitivity of the CPI to Exchange Rates. NBER Working Paper 12121.

[7] Campa, José Manuel and Linda S. Goldberg, 2006b. Pass-Through of Exchange Rates to Consumption Prices: What has changed and why?, NBER Working Paper 12547.

[8] Campa, José Manuel and Jose M. Gonzáles Mínguez, 2006. Differences in Exchange Rate Pass-Through in the Euro Area. European Economic Review 50, 121-145.

[9] Campbell, Jeffrey R. and Hugo A. Hopenhayn, 2005. Market Size Matters, Journal of Industrial Economics 53, 1-25.

[10] Caves, Richard E., 1998. Industrial Organization and New Findings on the Turnover and Mobility of Firms, Journal of Economic Literature 36, $1947-82$.

[11] Eckel, Carsten, 2008. International Trade and Retailing, University of Bamberg, mimeo.

[12] Economist, 2008. The Germans Are Coming. Vol. 388, no. 8593, 53-54.

[13] Fishman, Charles 2006. The Wal-Mart Effect. (New York: Penguin Press).

[14] Foreign Trade Association (2002). Challenges and Requirements for Global Sourcing of Apparel. (Brussels: FTA).

[15] Foster, Lucia S.; Haltiwanger, John, and C.J. Krizan, 2006. Market Selection, Reallocation and Restructuring in the US Retail Trade Sector in the 1990s, Review of Economics and Statistics 88 (4), 748-58.

[16] Francois, Joseph and Ian Wooton, 2008. Market Structure and Market Access. CESifo Working Paper 2239. 
[17] Francois, Joseph, Miriam Manchin and Hanna Norberg, 2008. Distribution services and differential producer and consumer price impacts of trade. University of Linz, mimeo.

[18] Haskel, Jonathan and Raffaella Sadun, 2009. Regulation and UK retailing productivity: Evidence from micro data. CEPR Discussion Paper No. 7140 .

[19] Hellerstein, Rebecca, 2008. Who Bears the Cost of a Change in the Exchange Rate? Pass-Through Accounting for the Case of Beer. Journal of International Economics 76, 14-32.

[20] Jacobson, Paul M., 2006. The Structure of Retail in Canada, Jacobson Consulting Inc., report prepared for the Retail Council of Canada in partnership with Industry Canada.

[21] Jarmin, Ron S.; Klimek, Shawn D. and Javier Miranda, 2004. Firm Entry and Exit in the US Retail Sector: 1977-1997, Center for Economic Studies, US Bureau of the Census, CES 04-17.

[22] Jarmin, Ron S.; Klimek, Shawn D. and Javier Miranda, 2005. The Role of Retail Chains: National, Regional and Industry Results, Center for Economic Studies, US Bureau of the Census, CES 05-30.

[23] Javorcik, Beata, Wolfgang Keller, and James Tybout, 2006. Openness and Industrial Responses in a Wal-Mart World: A Case Study of Mexican Soaps, Detergents and Surfactant Producers, NBER Working Paper 12457.

[24] Melitz, Marc J. and Gianmarco I.P. Ottaviano, 2008. Market Size, Trade and Productivity, Review of Economic Studies 75(1), 295-316.

[25] Miyagiwa, Kaz, 1993. Reforming the Japanese Distribution System: Will It Boost Exports to Japan? Japan and the World Economy 5, $321-336$.

[26] Raff, Horst and Nicolas Schmitt, 2008. Buyer Power in International Markets. Kiel Institute Discussion Paper.

[27] Richardson, Martin, 2004. Trade Policy and Access to Retail Distribution. Review of International Economics 12, 676-688. 
[28] Schivardi, Fabiano and Eliana Viviano, 2008. Entry Barriers and Retail Trade, Bank of Italy, mimeo.

[29] Waterson, Michael, 1984. Economic Theory of Industry. Cambridge University Press, Cambridge.

[30] Zentes, Joachim, Constantin Hilt, and Peter Domma, 2007. Handelsmonitor Spezial: Global Sourcing im Einzelhandel. Deutscher Fachverlag, Frankfurt am Main. 


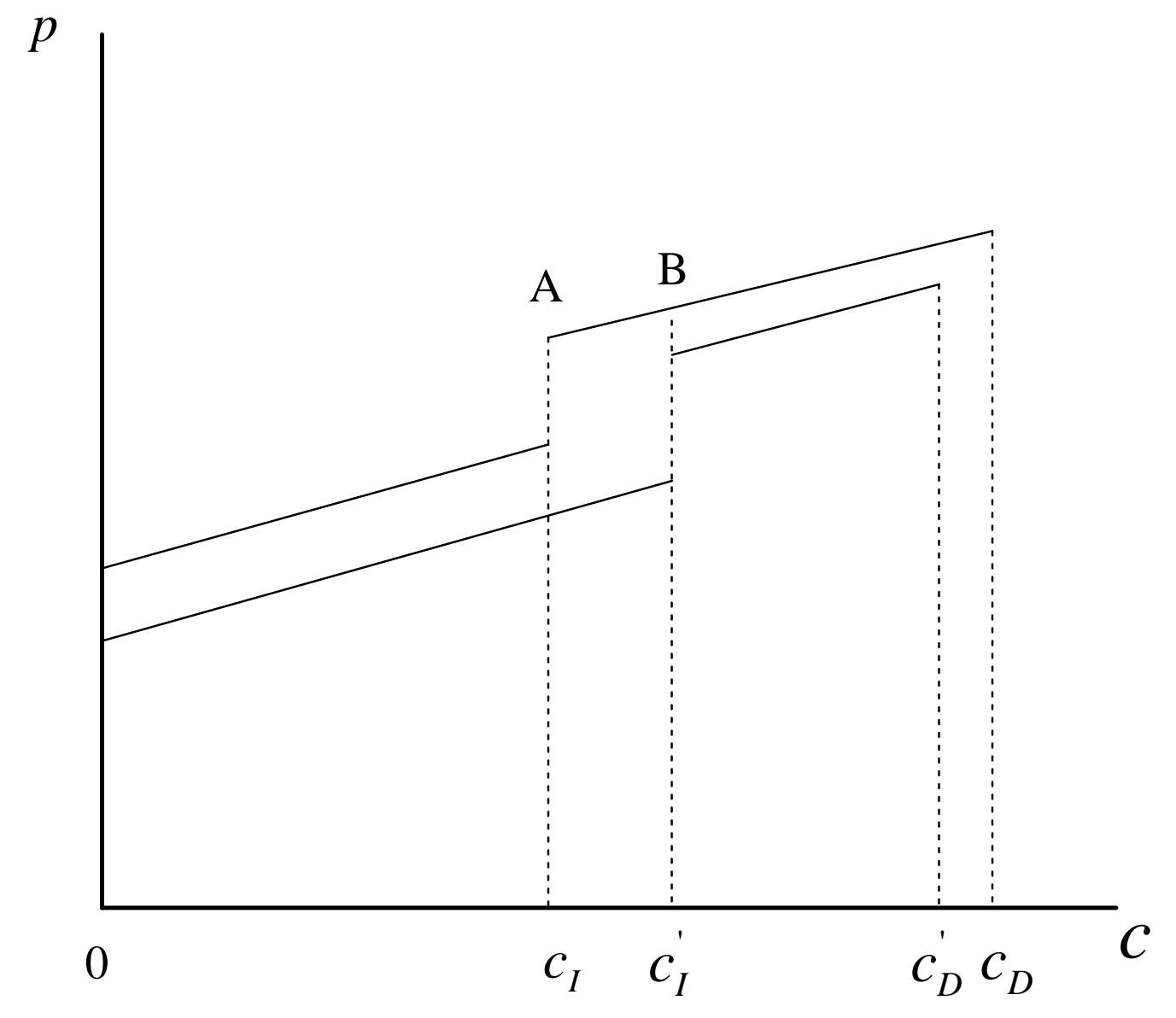

Figure 1: Prices and Pass-Through 


\section{CESifo Working Paper Series}

for full list see www.cesifo-group.org/wp

(address: Poschingerstr. 5, 81679 Munich, Germany, office@cesifo.de)

2753 Daniel G. Arce, Dan Kovenock and Brian Roberson, Suicide Terrorism and the Weakest Link, August 2009

2754 Mario Larch and Wolfgang Lechthaler, Comparative Advantage and Skill-Specific Unemployment, August 2009

2755 Horst Raff and Nicolas Schmitt, Buyer Power in International Markets, August 2009

2756 Seppo Kari, Hanna Karikallio and Jukka Pirttilä, The Impact of Dividend Taxation on Dividends and Investment: New Evidence Based on a Natural Experiment, August 2009

2757 Mirco Tonin and Michael Vlassopoulos, Disentangling the Sources of Pro-social Behavior in the Workplace: A Field Experiment, August 2009

2758 Nicole Grunewald and Inmaculada Martínez-Zarzoso, Driving Factors of Carbon Dioxide Emissions and the Impact from Kyoto Protocol, August 2009

2759 Yu-Fu Chen and Michael Funke, Booms, Recessions and Financial Turmoil: A Fresh Look at Investment Decisions under Cyclical Uncertainty, August 2009

2760 Jan-Egbert Sturm and Jakob de Haan, Does Central Bank Communication really Lead to better Forecasts of Policy Decisions? New Evidence Based on a Taylor Rule Model for the ECB, August 2009

2761 Larry Karp, Sacrifice, Discounting and Climate Policy: Five Questions, August 2009

2762 Marianna Belloc and Samuel Bowles, International Trade, Factor Mobility and the Persistence of Cultural-Institutional Diversity, August 2009

2763 Charles Noussair and Fangfang Tan, Voting on Punishment Systems within a Heterogeneous Group, August 2009

2764 Birgit Bednar-Friedl and Karl Farmer, Internationally Coordinated Emission Permit Policies: An Option for Withdrawers from the Kyoto Protocol?, August 2009

2765 Pierre M. Picard and David E. Wildasin, Labor Market Pooling, Outsourcing and Labor Contracts, August 2009

2766 Stefan Voigt and Lorenz Blume, The Economic Effects of Federalism and Decentralization - A Cross-Country Assessment, August 2009

2767 David S. Jacks, Christopher M. Meissner and Dennis Novy, Trade Booms, Trade Busts, and Trade Costs, August 2009 
2768 Mario Jametti and Thomas von Ungern-Sternberg, Hurricane Insurance in Florida, August 2009

2769 Alessandro Balestrino, Kind of Black: The Musicians' Labour Market in Italy, August 2009

2770 Yosr Abid Fourati and Cathal O’Donoghue, Eliciting Individual Preferences for Pension Reform, August 2009

2771 Christian Breuer and Chang Woon Nam, VAT on Intra-Community Trade and Bilateral Micro Revenue Clearing in the EU, August 2009

2772 Choudhry Tanveer Shehzad, Jakob De Haan and Bert Scholtens, Growth and Earnings Persistence in Banking Firms: A Dynamic Panel Investigation, August 2009

2773 Erdal Yalcin, Uncertain Productivity Growth and the Choice between FDI and Export, August 2009

2774 Klaus Abberger, Wolfgang Nierhaus and Shynar Shaikh, Findings of the Signal Approach for Financial Monitoring in Kazakhstan, September 2009

2775 Sascha O. Becker, Francesco Cinnirella and Ludger Woessmann, The Trade-off between Fertility and Education: Evidence from before the Demographic Transition, September 2009

2776 Thomas Aronsson and Erkki Koskela, Optimal Income Taxation, Outsourcing and Policy Cooperation in a Dynamic Economy, September 2009

2777 Joel Slemrod, Old George Orwell Got it Backward: Some Thoughts on Behavioral Tax Economics, September 2009

2778 Cagri Seda Kumru and Athanasios C. Thanopoulos, Social Security Reform and Temptation, September 2009

2779 Alessandro Bucciol and Roel M. W. J. Beetsma, Inter- and Intra-generational Consequences of Pension Buffer Policy under Demographic, Financial and Economic Shocks, September 2009

2780 Eduardo Strube and Marcelo Resende, Complementarity of Innovation Policies in the Brazilian Industry: An Econometric Study, September 2009

2781 Henry Tulkens and Vincent van Steenberghe, "Mitigation, Adaptation, Suffering": In Search of the Right Mix in the Face of Climate Change, September 2009

2782 Maria L. Loureiro, Anna Sanz-de-Galdeano and Daniela Vuri, Smoking Habits: Like Father, Like Son, Like Mother, Like Daughter, September 2009

2783 Momi Dahan, Tehila Kogut and Moshe Shalem, Do Economic Policymakers Practice what they Preach? The Case of Pension Decisions, September 2009 
2784 Eytan Sheshinski, Uncertain Longevity and Investment in Education, September 2009

2785 Nannette Lindenberg and Frank Westermann, How Strong is the Case for Dollarization in Costa Rica? A Note on the Business Cycle Comovements with the United States, September 2009

2786 Leif Danziger, Noncompliance and the Effects of the Minimum Wage on Hours and Welfare in Competitive Labor Markets, September 2009

2787 Gerlinde Fellner, Rupert Sausgruber and Christian Traxler, Testing Enforcement Strategies in the Field: Legal Threat, Moral Appeal and Social Information, September 2009

2788 Gabriel J. Felbermayr, Mario Larch and Wolfgang Lechthaler, Unemployment in an Interdependent World, September 2009

2789 Sebastian G. Kessing, Federalism and Accountability with Distorted Election Choices, September 2009

2790 Daniel Gros, Global Welfare Implications of Carbon Border Taxes, September 2009

2791 Louis N. Christofides, Michael Hoy and Ling Yang, The Gender Imbalance in Participation in Canadian Universities (1977-2005), September 2009

2792 Jan K. Brueckner and Robert W. Helsley, Sprawl and Blight, September 2009

2793 Vidar Christiansen and Stephen Smith, Externality-correcting Taxes and Regulation, September 2009

2794 John Beirne, Guglielmo Maria Caporale, Marianne Schulze-Ghattas and Nicola Spagnolo, Global and Regional Spillovers in Emerging Stock Markets: A Multivariate GARCH-in-mean Analysis, September 2009

2795 Rüdiger Pethig and Frieder Kolleß, Asymmetric Capital-Tax Competition, Unemployment and Losses from Capital Market Integration, September 2009

2796 Ngo Van Long, Horst Raff and Frank Stähler, Innovation and Trade with Heterogeneous Firms, September 2009

2797 Margit Osterloh and Bruno S. Frey, Research Governance in Academia: Are there Alternatives to Academic Rankings?, September 2009

2798 Thiess Buettner and Clemens Fuest, The Role of the Corporate Income Tax as an Automatic Stabilizer, September 2009

2799 Annette Alstadsæter, Measuring the Consumption Value of Higher Education, September 2009

2800 Peter Friedrich, Chang Woon Nam and Janno Reiljan, Local Fiscal Equalization in Estonia: Is a Reform Necessary?, September 2009 
2801 Evžen Kočenda and Jan Hanousek, State Ownership and Control in the Czech Republic, September 2009

2802 Michael Stimmelmayr, Wage Inequality in Germany: Disentangling Demand and Supply Effects, September 2009

2803 Biswa N. Bhattacharyay, Towards a Macroprudential Surveillance and Remedial Policy Formulation System for Monitoring Financial Crisis, September 2009

2804 Margarita Katsimi, Sarantis Kalyvitis and Thomas Moutos, "Unwarranted" Wage Changes and the Return on Capital, September 2009

2805 Christian Lessmann and Gunther Markwardt, Aid, Growth and Devolution, September 2009

2806 Bas Jacobs and Dirk Schindler, On the Desirability of Taxing Capital Income to Reduce Moral Hazard in Social Insurance, September 2009

2807 Hans Gersbach and Noemi Hummel, Climate Policy and Development, September 2009

2808 David E. Wildasin, Fiscal Competition for Imperfectly-Mobile Labor and Capital: A Comparative Dynamic Analysis, September 2009

2809 Johan Eyckmans and Cathrine Hagem, The European Union's Potential for Strategic Emissions Trading through Minimal Permit Sale Contracts, September 2009

2810 Ruediger Bachmann and Christian Bayer, The Cross-section of Firms over the Business Cycle: New Facts and a DSGE Exploration, October 2009

2811 Slobodan Djajić and Michael S. Michael, Temporary Migration Policies and Welfare of the Host and Source Countries: A Game-Theoretic Approach, October 2009

2812 Devis Geron, Social Security Incidence under Uncertainty Assessing Italian Reforms, October 2009

2813 Max-Stephan Schulze and Nikolaus Wolf, Economic Nationalism and Economic Integration: The Austro-Hungarian Empire in the Late Nineteenth Century, October 2009

2814 Emilia Simeonova, Out of Sight, Out of Mind? The Impact of Natural Disasters on Pregnancy Outcomes, October 2009

2815 Dan Kovenock and Brian Roberson, Non-Partisan 'Get-Out-the-Vote' Efforts and Policy Outcomes, October 2009

2816 Sascha O. Becker, Erik Hornung and Ludger Woessmann, Catch Me If You Can: Education and Catch-up in the Industrial Revolution, October 2009

2817 Horst Raff and Nicolas Schmitt, Imports, Pass-Through, and the Structure of Retail Markets, October 2009 